\title{
AZ ÉGHAJLATVÁLTOZÁS KÉRDÉSE A MAGYAR ERDŐGAZDÁLKODÓK KÖRÉBEN
}

\author{
Jankó Ferenc 1,4, Bertalan Laura', Pappné Vancsó Judit², Ormos Balázs³, \\ Németh Nikoletta' ${ }^{1}$ és Hoschek Mónika ${ }^{1}$ \\ ${ }^{1}$ Soproni Egyetem, Lámfalussy Sándor Közgazdaságtudományi Kar \\ ${ }^{2}$ Roth Gyula Erdészeti, Faipari, Kertészeti, Környezetvédelmi Szakgimnázium, Szakközépiskola és Kollégium \\ ${ }^{3}$ Ormos Erdö Bt. \\ ${ }^{4}$ Eötvös Loránd Tudományegyetem, Természettudományi Kar
}

\begin{abstract}
Kivonat
Tanulmányunkban országos kérdőíves mintán és interjúk segítségével vizsgáltuk az erdőgazdálkodók éghajlatváltozásérzékelését és adaptációs tevékenységét. Eredményeink szerint leginkább a hótakarós napok számának csökkenését érzékelik a válaszadók, ám különbségek mutatkoztak az éghajlatváltozás érzékelésében a válaszadók földrajzi elhelyezkedése, és a kezelt erdöterületek jellege alapján. Szakirodalmi összevetésben elmondható, hogy a magyar erdésztársadalom a felkészülés szakaszában van, megvalósított adaptációról csak a válaszadók 16\%-a számolt be, ugyanakkor többen jelezték, hogy ebben a jogszabályi elöírások képeznek akadályt. A már alkalmazkodókról elmondható, hogy közöttük átlagban nagyobb fokú az aggódás, régebb óta érzékelik és jelentősebbnek tekintik a problémát, saját gazdálkodásuk eredményességét tekintve is. Megállapítottuk, hogy az állami erdőgazdaságok nem alkalmazkodnak jobban, s a magas fokú aggódásról sem mondható el, hogy blokkolná az éghajlatváltozáshoz történő alkalmazkodást, a természetvédelmi tényező pedig a kérdöives adatok szerint ugyan nem hátráltatja az adaptációt, több interjúalany viszont erröl számolt be.
\end{abstract}

Kulcsszavak: éghajlatváltozás, erdészetek, érzékelés, adaptáció, Magyarország.

\section{CLIMATE CHANGE ATTITUDES AND ADAPTATION OF HUNGARIAN FOREST MANAGERS}

\begin{abstract}
This study utilizes a national questionnaire sample and interviews to examine attitudes to climate change as well as perceptions and adaptation activities among Hungarian forestry managers. The results show the respondents addressing climatic changes are concerned mostly by the decrease in the number of snow-covered days, but differences of opinion can be attributed to geographical location and the forest areas managed. Hungarian forest management is still in the preparation phase with only $16 \%$ of respondents reporting the implementation of climate change adaptation measures; however, many foresters claim this is often hindered by legislative constraints. Those who have implemented adaptation measures show an increased concern toward climate change on average; they have been aware of climate change for a longer time and regard it as a serious problem affecting their management activities. The study has evidence that state forest managers do not adapt better than private foresters do, high level of concern and nature conservation factors do not hinder adaptation. However, during the interviews respondents reported that nature conservation factors do, in fact, hinder adaptation processes.
\end{abstract}

Keywords: climate change, forestries, perception, adaptation, Hungary. 


\section{BEVEZETÉS}

Az éghajlatváltozás régóta a figyelem középpontjában van az erdészeti szektorban, nemcsak a kutatásokat határozza meg egyre inkább, hanem az erdészeti politikát is (NES 2016). A kutatások elsősorban arra irányulnak, hogy az erdőterületeken érzékelhető természeti és ökológiai folyamatokat értsék meg, és jelezzék azokat előre a klimatikus trendekkel összefüggésben, tehát alapvetően természettudományos megközelitésüek (Mátyás 2006a, Somogyi 2003). A magyarországi kutatások nemzetközi összefüggésekben is fontos szerepet kapnak az erdő-sztyepp átmenet vizsgálatában (Mátyás \& Sun 2014) Jelen tanulmány empirikus vizsgálatok bázisán az emberi tényező szerepére koncentrál; társadalomtudományi elemzésünk az ágazat szereplőinek a viszonyát kívánja feltárni a megváltozó klíma érzékelése, felfogása, az ahhoz történő alkalmazkodás tekintetében. Kutatásunknak két csomópontja, két fő kérdése van: az egyik az éghajlatváltozás érzékelése, a másik az alkalmazkodási válaszok, stratégiák elemzése, ezek mikéntje a hazai erdőgazdálkodók körében.

Az első kutatási kérdéssel kapcsolatban egy hipotézist fogalmaztuk meg: a hely, a kezelt erdőterület jellege, termőhelyi és mikroklimatikus adottságai befolyásolják az éghajlatváltozás érzékelését. A másodiknál a fő cél az adaptáció motivációinak, tényezőinek a feltárása. Ide vonatkozóan három hipotézisünk van: az állami erdőgazdaságok felkészültebbek, tudatosabbak az éghajlatváltozással való összefüggésben; az erdők természetvédelmi oltalma megnehezíti az alkalmazkodást; a problémával kapcsolatos túlzott aggódás blokkolja az adaptációt, a cselekvést.

\section{SZAKIRODALMI ÁTTEKINTÉS}

Az éghajlatváltozás tapasztalásának, érzékelésének témája széles körben kutatott, amely területen a közvéleményt célzó kutatások mellett a „természettel” dolgozókra, így a mezőgazdasági és az erdészeti szakemberekre is kiterjed a figyelem, hiszen ők munkájukból kifolyóan hitelesebben tudnak beszámolni a jelenségröl (Weber 2010). Röviden utalunk itt Egan \& Mullin (2012), Akerlof et al. (2013), Hamilton \& Stampone (2013) munkáira, akik a megkérdezettek tapasztalatait a valós klímaadatokkal vetették össze, Myers et al. (2013) pedig demonstrálta a tapasztalati tanulás esetét, ami azt jelenti, hogy a személyes tapasztalás növekvő klímaváltozás-hithez vezet, és annak fordítottját, a motivált gondolkodásét, amikor a magas fokú bizonyosság, hit befolyásolja az érzékelést és a tapasztalatot. Az első így az azért hiszem mert látom, a második pedig az azért látom, mert hiszem esete. Ezeket a valósában nehéz elválasztani. Több tanulmány emeli ki a személyes tapasztalat és a cselekvési motiváltság közötti kapcsolatot is (Lorenzoni \& Pidgeon 2006; Broomell et al. 2015), de a társadalomföldrajzi megközelítések a hely és az időbeliség szerepét is hangsúlyozzák ebben a vonatkozásban (Brace \& Geoghegan 2010). 
Az erdészeti témára fókuszálva a nemzetközi szakirodalomban ma már több olyan tanulmányt találni, amelyek hasonló kérdésfeltevésekkel és módszerekkel készültek. A több országban - döntően Európa nyugati felén - készült esettanulmányok tanulságait összegezve elmondható, hogy egyre inkább foglalkoztatja az erdészeti szakembereket az éghajlatváltozás, azonban az alkalmazkodási cselekvés még többnyire alacsony intenzitású. A téma kutatói az alkalmazkodás számos személyes, vagy földrajzi tényezőire is rámutattak. Az ide vonatkozó kutatások sorában említhetjük Blennow (2012) Svédországban három mintaterületen, két időszakra végzett kérdőives felmérését, ahol azt tapasztalta, hogy az adaptációs intézkedések fejlődtek, kiterjedtek az idő múlásával, összefüggésben a megkérdezettek kockázatérzékelésével, különösen a déli régiókban. Milad et al. (2012) Németországban készített tizenhárom erdész-interjút, hogy teszteljék azt, hogy a klímaadaptáció mennyire van már benne a gyakorlatban. Eredményeikben arról számoltak be, hogy bár a megkérdezettek, függően attól, hogy mennyire kitett régiójuk az éghajlatváltozásnak figyelembe veszik az éghajlatváltozást, esetleg tervezik is az adaptációt, munkájuk során azonban ennek még kevés eredménye van, látható, megvalósított stratégiák formájában. Detten \& Faber (2013) országos kérdőívezése és interjúzása inkább a döntéshozásra, tervezésre helyezte a hangsúlyt. Ide kapcsolódóan Yousefpour \& Hanewinkler (2015) ugyancsak németországi vizsgálatával az adaptációs és mitigációs lehetőségek bizonytalanságaira mutatott rá.

Lawrence \& Marzano (2014) dél-wales-i területen végzett interjús vizsgálatokat feltárva az adaptáció kérdőjeleit. Egyrészt arra mutattak rá, hogy nem igazán aggodalmaskodnak a klíma miatt a válaszadók, másrészt, hogy a fafajpolitikát illetően megoszlottak a vélemények azok között, akik az őshonos fajokat, a lucfenyőt vagy az új fajokat támogatták. Hasonlóképpen a klíma bizonytalanság, illetve -kockázatok eltérő felfogásaira, adaptációban játszott szerepére mutatott rá Nagy-Britannia-szerte Petr et al. (2014). Furness \& Nelson (2012) Kanadában, British Columbiában kutatták az érzékelés és a válaszadás kérdését, helyi közösségi erdészeti szervezetek kérdőives vizsgálatával, ugyanitt készült Nelson et al. (2016) tanulmánya, amely az erdészeti szakemberek adaptációs hajlandóságát elemezte. Lenart \& Jones (2014) pedig a klímaváltozásba vetett hit szerepét vizsgálta a cselekvési hajlandóságban az USA-ban, kimutatva az összefüggést.

Ezek mellett más hangsúlyokkal egyre több írást lelni fel az utóbbi években, így Johnston \& Hesseln (2012) \& Gameren és Zaccai (2015) az adaptációs kapacitásra, képességre fókuszál kanadai, illetve belga interjúvizsgálataival, ugyanezzel a módszerrel Blades et al. (2016) a klímatudomány elfogadottságát tesztelte Sziklás-hegység-beli erdészekkel, Andersson et al. (2017) pedig svédországi-skóciai összehasonlításával arra mutatott rá, hogy az adaptáció, az adaptációs kapacitás befolyásolásban az intézményi környezet, ágazati hagyományok legalább annyira fontos tényezők, mint a személyes tulajdonságok, s az érzékelés. Mostegl et al. (2017) ezer fös mintán vizsgálta Ausztriában az éghajlatváltozás szerepét az erdészeti döntéshozásban. Vizsgálatuk érdekessége az alkalmazott környezetértékelési módszer, az ún. diszkrét választási kísérlet volt. Lakkonen et al. (2018) vizsgálatának különlegessége a helyben, a kezelt erdöben végzett interjúk és ezek kognitív térképezése és elemzése volt, mindazonáltal ők is rámutattak az érzékelés bizonytalanságaira. 
Az első, több régiót átfogó vizsgálat Blennow et al. (2012) tanulmányában olvasható, amelyet az érzékelés és a cselekvés koncepcionális megközelítése köré szerveztek. Svédországban, Németországban és Portugáliában folytatott kérdőives vizsgálataikkal rámutattak arra, hogy a klímaváltozás jelenségébe vetett hit és a tapasztalat nem meglepő módon erős összefüggésben van a cselekvéssel, emellett ezekben a relációkban éles regionális különbségekre mutattak rá. Ez az írás több más tanulmánynak módszertani alapot nyújtott, így például Sousa-Silva et al. (2016) is az érzékelés-adaptáció kapcsolatot kutatta Belgiumban, háromszáz fős erdész mintán. Raftoyannis et al. (2014) a mediterrán országokban végzett összehasonlító kutatásokat, vizsgálva a tűzbiztonsági intézkedések, a közvélemény figyelemfelkeltése és az üzemanyag használat szerepét az éghajlatváltozáshoz való adaptációban. Blennow et al. (2016) később arra hívta fel a figyelmet, hogy az erdészek között - a szakirodalomban a közvélekedéssel kapcsolatosan elterjedt összefüggéssel ellentétben az egyetemi végzettség, a magasabb tudományos képzettség nem polarizálja az éghajlatváltozásról való gondolkodást és a cselekvési hajlandóságot.

\section{MÓDSZERTAN}

2016-2017 folyamán írásban, majd telefonon megkerestük a 22 állami erdőgazdaságot és a magánerdészeteket, hogy elsősorban erdészeti, azaz operatív szinten dolgozó munkatársaik, illetve az erdészeti szakszemélyzet révén töltsék ki a kérdőívünket. A felmérés során 186 kiértékelhető kérdőívhez jutottunk. A kitöltők közül az alap adatokat áttekintve - amelyre 10 kérdés vonatkozott - kilencen voltak nők, életkori megoszlás szerint 1950 és 1989 közötti születésű volt a kitöltők több, mint 93\%-a, legnépesebb csoport 30\%-kal az 1970-79-es korosztály volt, őket követték az 1960-69-esek 26\%-kal. Településnagyság-típusra és megyére a felmérésünk lényegében reprezentatívnak mondható, minden településszintet és megyét az erdők megoszlásával arányosan közel megfelelően képviseltek a válaszadók.

A beérkezett válaszokat a gazdálkodás helye (település, erdészeti kistáj) alapján sík-, domb- és hegyvidéki kategóriába osztottuk be, a megoszlás itt 3:3:4-nek adódott. Egy másik bontásban az erdő-klíma viszonyok figyelembevételével négy nagyrégióra osztottuk Magyarországot, megkülönböztetve az Alföldet (27\%), Észak-Magyarországot (23), Dél-Dunántúlt (23; hozzá sorolva Zalát) és Észak-Dunántúlt (27).

Az erdőterületek megoszlására kérdőívünk a fő állományalkotó társulások, természetvédelmi kategóriák, és rendeltetés alapján kérdezett rá. Alanyaink kb. 2/3-a állami 1/3-a magán erdőgazdaságnál dolgozik. Meglehetősen kevés volt az olyan válaszadó, akinek egyoldalú, monokultúrás erdőterülete lenne Az állományalkotó társulásokat figyelembe véve az 1. táblázatban megjelölt csoportok kialakítására volt mód.

A kérdések következő blokkját a problémaérzékelés jelentette (6 kérdés), az éghajlatváltozással kapcsolatos információszerzésre, a tapasztalás és a probléma aktualitásának időbeli dimenziójára, fontosságára vonatkozó kérdésekkel. Öt pontos Likert-skála alkalmazá- 
sával hat kérdésből álló (három-három pozitív és negatív megfogalmazással) aggódás kérdéssort alkottunk, amelyek megfelelő aggregálásával egy 6 és 30 közötti intervallumon (esetünkben 11 és 30 között) mozgó, 23,0-as átlagú aggódás-indexet képeztünk. Ugyanitt fontos kérdés volt az, hogy az erdészek lakó, illetve gazdálkodási helyüket tekintve milyen klimatikus vagy időjárási jelenségeket tulajdonítanak az éghajlatváltozásnak. Ezekből egy max. 12es értéket felvevő klíma-romlás-indexet alakítottunk ki (átlag: 8,2), minden válaszadónál öszszeszámolva azon válaszokat, amelyek ez irányba mutatnak (pl. összemosódó évszakok, hótakaróval fedett napok száma csökkent stb.). A fordított irányú mutatónál adott részkérdéseknél a változás hiánya egy, a pozitív irányú változás kettő pontot ért (pl. a nem változó, illetve a növekvő évi csapadékmennyiség), így a „klíma-javulás-index” elméletben 21 pontot vehetett fel, viszont csak 1 és 11 közötti értékek adódtak (3,2-es átlaggal).

A következő kérdésblokk a gazdálkodásra való hatást, a kiszolgáltatottságot, és az alkalmazkodást vizsgálta (6 kérdés). Utóbbi kapcsán nyitott kérdésekkel is megkérdeztük az adott esetben már elvégzett adaptációs cselekvést, illetve a tervbe vett intézkedéseket.

1. táblázat: $A$ válaszadók csoportjai az erdők fö állományalkotó társulás alapján, $N$.

Table 1: Groups of respondents according to the major species of forest composition.

\begin{tabular}{|l|c|c|}
\hline $\begin{array}{l}25 \% \text { feletti bükkössel (átlag: 10,6) rendelkezik, } \\
\text { gyertyános-tölgyes 45\%, cseres és tölgyes 40\%, fenyves 20\% alatt: }\end{array}$ & 29 & 1. csoport \\
\hline $\begin{array}{l}20 \% \text { feletti fenyvessel (átlag: 11,4) rendelkezik, bükk 25\%, } \\
\text { gyertyános-tölgyes 30\%, tölgyes 30\%, cseres 32\% alatt: }\end{array}$ & 23 & 2. csoport \\
\hline $\begin{array}{l}40 \% \text { feletti cseresekkel (átlag: } 14,5) \text { rendelkezik, bükk 25\%, } \\
\text { gyertyános-tölgyes 30\%, fenyves 20\%, egyéb keménylombos 30\% alatt: }\end{array}$ & 21 & 3. csoport \\
\hline $\begin{array}{l}31 \% \text { feletti egyéb keménylombos erdövel (átlag: 23,5) rendelkezik, bükk } \\
10 \%, \\
\text { alatt: tölgyes 50\%, cseres 30\%, fenyves 20\%, egyéb lágylombos } 45 \%\end{array}$ & 56 & 4. csoport \\
\hline $\begin{array}{l}\text { Bükk 25\%, cseres 35\%, fenyves 20\%, egyéb keménylombos 25\% alatt } \\
\text { és a gyertyános-tölgyes átlag (18,1) felett: }\end{array}$ & 30 & 5. csoport \\
\hline $\begin{array}{l}\text { Bükk 25\%, cseres 40\%, fenyves 20\%, egyéb keménylombos 25\% alatt } \\
\text { és a gyertyános-tölgyes átlag (18,1) alatt: }\end{array}$ & 27 & 6. csoport \\
\hline Összesen: & 186 & \\
\hline
\end{tabular}

A kérdőívezést egy országos körben végzett interjúzással egészítettük ki, további információk szerzése, a kérdőíves eredmények ütköztetése céljából. Összesen 16 erdőgazdálkodót kérdeztünk meg, figyelve arra, hogy a megkérdezettek a gazdálkodás helyszínét tekintve képviseljék a jelentősebb tájegységeket, illetve vegyesen legyenek állami és magán erdészetek gazdálkodói. Az interjúalanyok kiválasztásánál további szempont volt, hogy lehetőség szerint több évtizedes szakmai és vezetői tapasztalattal rendelkezzenek. Így az in- 
terjúalanyok nagyrészt 60 év körüliek, néhány esetben nyugalmazott erdészetvezetök voltak, egy esetben erdőfelügyelő. Az interjúkérdések segítségével - hasonlóan a kérdőív céljaihoz - a klímaváltozás érzékelésére, annak pozitív és negatív hatásaira, az alkalmazott adaptációs stratégiákra, és a föbb akadályozó tényezőkre kérdeztünk rá.

\section{EREDMÉNYEK ÉS DISZKUSSZIÓ}

\section{Az éghajlatváltozás érzékelése}

A felmérésben egyetlen fő mondta azt, hogy nem hallott az éghajlatváltozásról, 13-en pedig nem tapasztalták azt. A legfontosabb információforrásnak a hagyományos és internetes média, illetve a szakmai folyóiratok, rendezvények adódtak $90 \%$ körüli említésekkel. Yousefpour \& Hanewinkler (2015) Németországban a szakmai képzéseket, a médiát és a szakirodalmat emelte ki hasonló tekintetben.

A többség (42\%) az elmúlt 10 évet jelölte meg a klímaváltozás időhorizontjaként, vagyis nagyjából a 2000-es évek dereka óta érzékelik a legtöbben a jelenséget. A rövidebb időszakot megjelölők mintegy 30\%-ot, a hosszabb időszakot megjelölők 22\%-ot tettek ki a mintában. Az interjúkban általában az 1980-as években jelentkező légköri aszályt és az azt követő szárazodást említették a klímaváltozás első jeleként, mely föként a lucosoknál okozott nagy károkat. De volt, aki már az 1970-es évek végén a cseres-tölgyesekben tapasztalt kocsánytalan tölgy pusztulást (Mátra) is ebben az összefüggésben említette meg. A kérdőívben is megkérdezett időjárási-klimatikus változások mellett (Id. alább) interjúalanyaink a talajvízszint erőteljes csökkenéséről és a hőmérséklet szélsőséges ingadozásáról is beszámoltak.

Egy következő kérdésnél a klímaváltozás problémájának aktualitására, egyúttal a jelenséggel kapcsolatos kételyekre kérdeztünk rá, itt a válaszadók abszolút többsége $(57 \%)$ mondta azt, hogy az éghajlatváltozás hatásait már saját bőrén érzi, saját szemével látja. Egy-harmados volt a válaszadók azon csoportja, akik szerint a klíma mindig is hatott és hatni fog az emberiségre, ök azok nagyjából, akik a problémát a távoli jövőbe kivetítőkkel egyetemben (4\%) kételkednek a probléma fontosságában. Egy ilyen kisebb válaszadói csoportról Yousefpour \& Hanewinkler (2015) is beszámolt, Mostegl et al. (2017) pedig 20\%-ra tette ezek arányát a kisbirtokos erdészek körében.

Az interjúk során jobban kiütközött, hogy a klímaváltozás emberi vagy természeti okait tekintve megoszlik a vélemény. Az antropogén tevékenységet föként a megváltozott földhasználat, a művi környezet növekedése, az ipar és a közlekedés környezetszennyező hatásai, illetve a nagymértékű fosszilis energiafogyasztás miatt tették felelőssé, ugyanakkor azt is többen megemlítették, hogy nem lehet tudni, hogy valójában a természeti folyamatok (vulkánok, szilikátok szén-dioxid kibocsátása) miatt bekövetkező klímaváltozáshoz milyen mértékben járul hozzá az emberi tevékenység.

Kérdőíves adataink alapján nyilvánvalóvá vált, hogy a megkérdezettek leginkább a saját ágazatukat, az erdőgazdálkodást tartják kitettnek a klímaváltozás hatásaival kapcsolatban, 
és ezt a hatást egy öt fokozatú skálán túlnyomóan negatívnak itélték meg. Ehhez hasonlóan értékelték a mezőgazdaságot és a természeti környezetet is.

Az időjárási jelenségeket az éghajlatváltozás vonatkozásában mérlegre tevő kérdés szólt arról, hogy mi az, ami jól látható, érzékelhető a saját lakóhelyet, gazdálkodási helyet tekintve. Összesitett adataink szerint a kép meglehetősen egyértelmü, csupán az évi csapadékmenynyiség az, ahol jelentősebb fokú bizonytalanság tapasztalható, itt a csökkenésről beszámolóknál többen voltak azok, akik szerint nincs változás. A leginkább problematikusnak pedig a hótakarós napok csökkenése, az aszályos időszakok gyakoriságának növekedése és az összemosódó évszakok jelensége adódott (1. ábra). Nyilván ez az eredmény meglehetősen ország-specifikus, más helyszíneken eltérő eredmények adódtak (vö. Furness \& Nelson 2012; Detten \& Faber 2013; Sousa-Silva et al. 2016) A módszertanban jelzett háromféle erdő-csoportosításban a válaszadók átlagos klíma-romlás-indexét a 2. ábra mutatja. Ez jelzi már azt, hogy a legnagyobb különbségek a regionális és az erdőtípus szerinti bontásban mutatkoztak, ezeket érdemes hát közelebbröl is megvizsgálni, amikor az érzékelés és a hely kapcsolatát vizsgáljuk, hiszen a domborzati típusok kapcsán a hegyvidékekre és a síkvidékekre is számos esetben igaz, hogy valamelyest kisebb mértékben tapasztalják a problémákat.

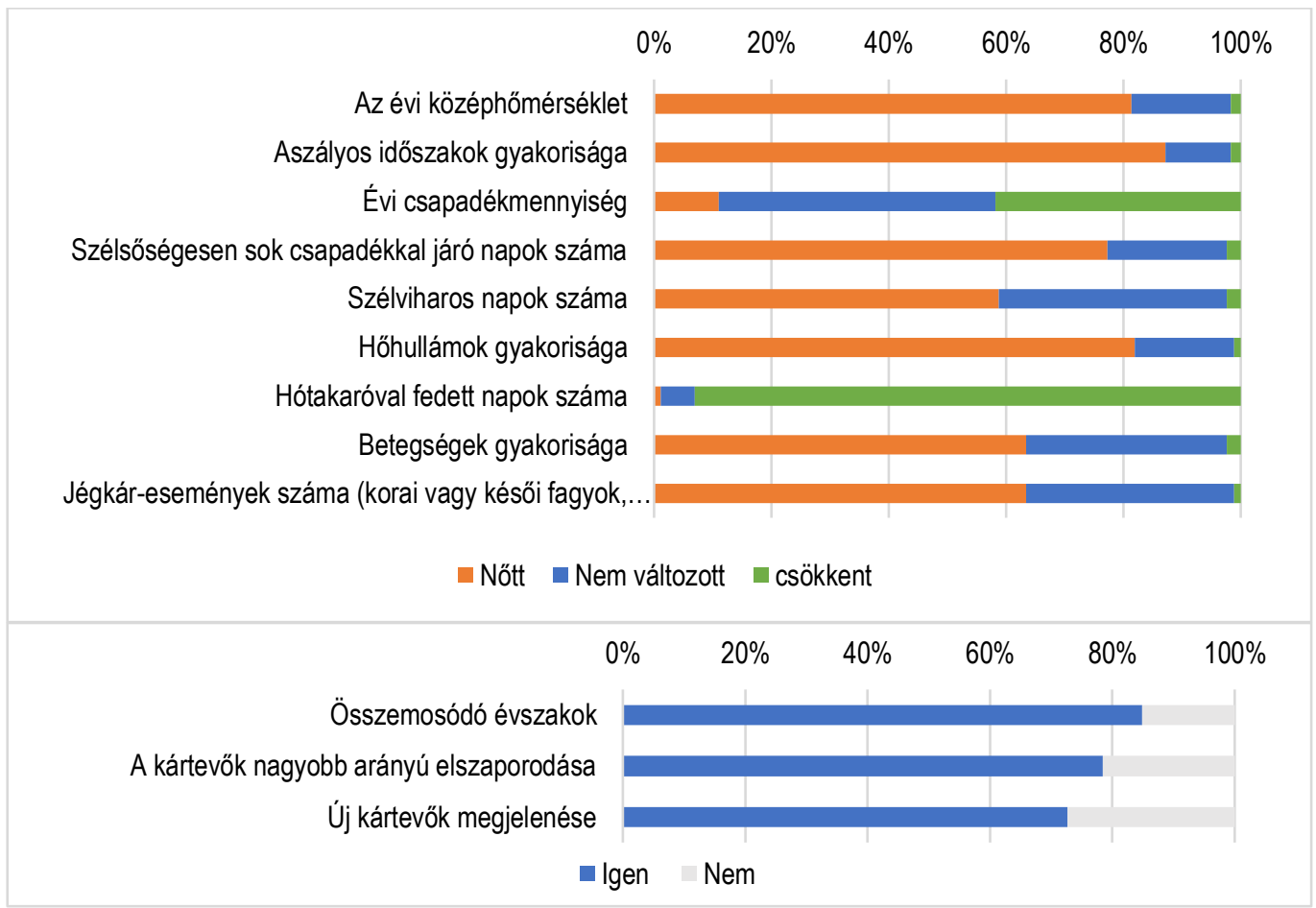

1. ábra: Az éghajlatváltozásnak tulajdonitott időjárási-klimatikus tényezők.

Figure 1: Factors of weather and change attributed to climate change. 


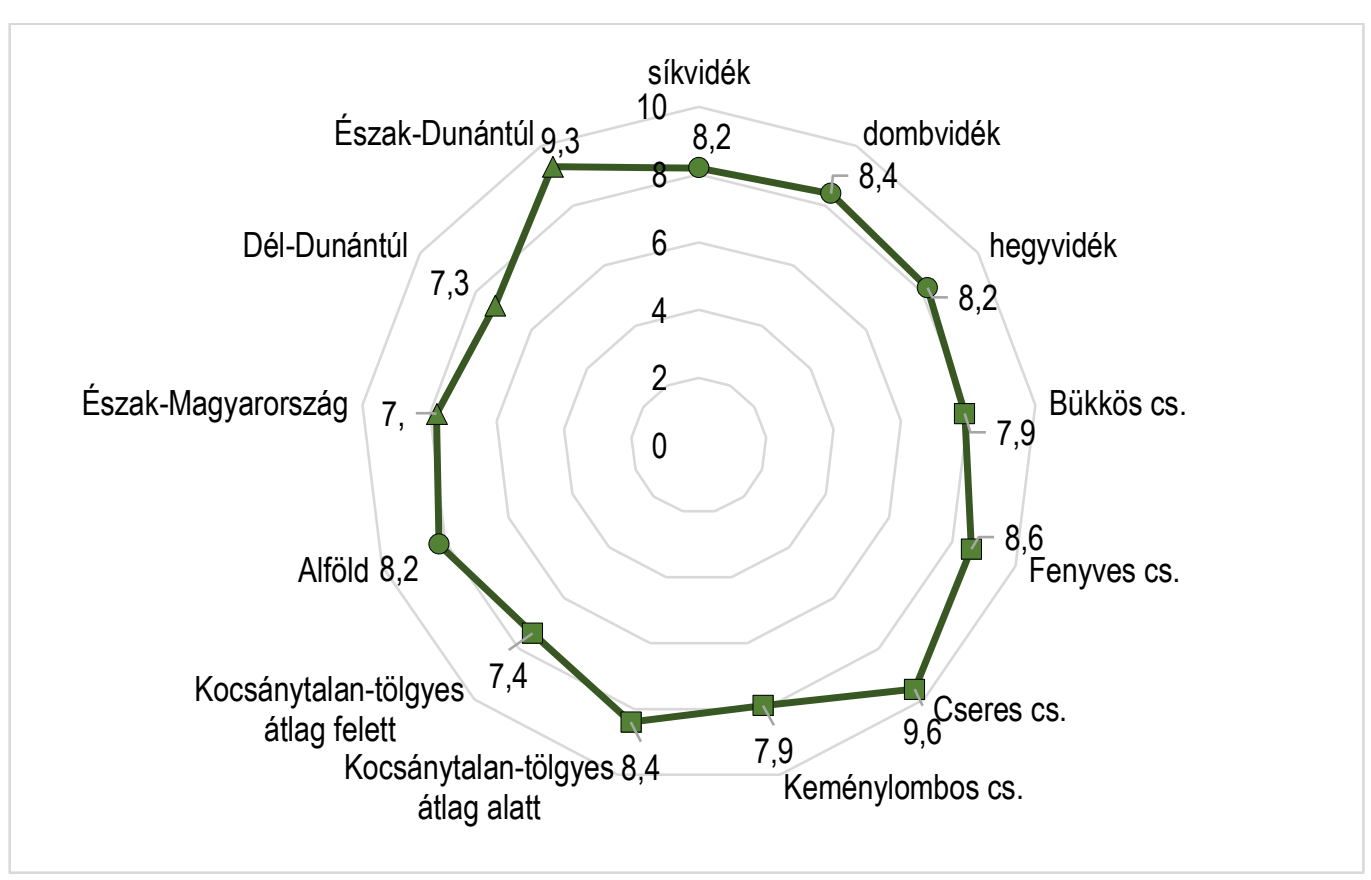

2. ábra: A klíma-romlás-indexek értékei az erdők elhelyezkedése és erdőcsoportja alapján (max. 12).

Figure 2: Indices of climate-worsening based on the location and types of forests (max. 12).

A jellegadó állományalkotó társulások alapján képzett csoportok esetében némiképp „beleillik a képbe", hogy a 40\% feletti cseresekkel rendelkező csoport válaszadói adták a legnagyobb arányú válaszokat az aszályos időszakok, a hőhullámok, a jégkárok gyakoriságának növekedése, az összemosódó évszakok, a kártevők vonatkozásában, egyebekben a „fenyves” csoport rendelkezik a legnagyobb értékekkel, amely viszont az évi csapadéköszszeg vagy az aszályos időszakok vonatkozásában a legnagyobb arányban számolt be növekedésről, illetve változatlanságról. Összességében változatlan időjárási mintázatokról leggyakrabban az egyéb keménylombos és a bükkös csoport számolt be.

A regionális csoportositás szerint talán még élesebb a kép. Az észak-magyarországi válaszadóknál a legkisebbek (bár ez itt is sok esetben $70 \%$ feletti értékeket jelent) a klímaromlást jelző válaszok, s legnagyobbak a változatlanságról tanúskodó feleletek. A 11 időjárási tényezőből 9 esetében (három holtversenyben) az Észak-Dunántúlon a legmagasabbak az értékek (összemosódó évszakok, évi középhőmérséklet növekedése, évi csapadékcsökkenés, aszályos időszakok, hőhullámok növekedése, szélviharos napok számának növekedése, kártevők nagyobb arányú elszaporodása, betegségek gyakoribbá válása, több jégkár), míg az Alföldön a leginkább kiugró a hótakaróval fedett napok csökkenésének érzékelése, s szintén az évi középhőmérsékletcsökkenés és az aszályos időszakok növekedése. A DélDunántúlon pedig a szélsőséges csapadékok növekedését és a kártevő problémát (nagyobb arányú elszaporodás, újak megjelenése) jelezték legnagyobb arányban. 
Még egyféleképpen igyekeztünk megnézni, hogy mi befolyásolhatja az éghajlatváltozás tapasztalását, voltaképpen milyen helyi karakter az, ahol nagyobb eséllyel kevésbé láthatók az éghajlatváltozás jelei. A klíma-javulás-indexet felhasználva, az átlag kétszeresét (6) elérökkel képeztünk egy 43 fös csoportot. Ezeknél - a fentiekkel összefüggésben - némiképp nagyobb a síkvidéki és hegyvidéki csoportba tartozók aránya, több a bükkös, a keménylombos és az átlag alatti gyertyános-tölgyes csoport (1., 4., 6. csoport). A minta korösszetételén az is látszik, hogy az idősebbek (1950-1959) fele akkora arányban vannak jelen, míg a legfiatalabbak (1980-1989) arányaiban másfélszer annyian. Ezzel összefügg, hogy a válaszadók többsége, majdnem fele csak az elmúlt néhány évben tapasztalta az éghajlatváltozást. Sokat mond, hogy ez a csoport nagyobb arányban számolt be - lásd részletesebben alább - a gazdálkodás eredményességének javulásáról vagy változatlanságáról a klímaváltozással összefüggésben, s azt is megjegyezhetjük, hogy némiképp kevésbé foglalkoztatja ezt a csoportot a probléma. Vagyis összességében megfogalmazhatjuk, hogy első hipotézisünket bizonyos mértékig elfogadhatjuk, van némi összefüggés a hely és az érzékelés között, továbbá az is látszik, hogy a tapasztalás mikéntje az alkalmazkodás módjára is kihat.

\section{Alkalmazkodás az éghajlatváltozáshoz}

Az egész mintát tekintve az mondható el, hogy a válaszadók többsége negatívan értékeli az éghajlatváltozás hatásait a gazdálkodásra, mintegy kétharmaduk romló, $13 \%$ sokat romló eredményességről számolt be. Ezzel összefüggésben ugyancsak mintegy kétharmadnyian mondták azt, hogy kiszolgáltatottnak érzik magukat, és összesen $31 \%$ nyilatkozta azt, hogy képes úrrá lenni a problémákon - e válaszadók nagyobb része a pénz függvényében válaszolta ezt. Úgy tủnik a tudás-nem-tudás, mint akadály igencsak nagy mértékben megjelenik ennél a kérdésnél - némileg ellentmondásban azzal, amit az érzékelésnél láttunk, vagy, amit alább a felkészülés adatai mondanak. Bár a kérdésfeltevés módja nem volt ugyanaz, mindenesetre Nelson et al. (2016) sokkal jobb arányokról számolt be Kanadában.

Viszont a többség komolyan foglalkozik a felkészüléssel: az ágazat alapvetően a felkészülés fázisában van, hiszen a válaszadók $40-50 \%$-a válaszolta azt, hogy valamilyen formában a szakmai felkészülésnél tart (kollégákkal értekezik, szakmai rendezvények, tanulmányok olvasása), igaz a már változtatók, alkalmazkodók aránya mindössze $16 \%$ (Id alább a 3. ábrát). Ez országos összevetésben meglehetősen alacsony: Blennow et al. (2012) Portugáliából több mint 50\%-ot, Németországból 48, Svédországból 20\%-ot, Sousa-Silva et al. (2016) Belgiumból 32\%-ot jelentett.

Az adaptációs döntés befolyásoló tényezőit Blennow et al. (2012) módszerével a 2. táblázatban elemezzük. A személyes jellemzők közül a településnagyságot, az erdőterületek jellemzői közül a dombvidéki és dél-dunántúli elhelyezkedést, illetve az átlag feletti cseres és fenyves faösszetételt lehet kiemelni - szemben azzal, hogy az érzékelésnél a KözépDunántúl emelkedett ki a legtöbb tényezőben. Azok, akik már alkalmazkodtak (valamelyest) 
az éghajlatváltozáshoz régebb óta érzékelik azt, jobban aggódnak, jelentősebb problémának tekintik, és ami kiváltképp fontos lehet, nemcsak az időjárási jelenségekben, hanem a saját gazdálkodásukban is jóval inkább érzékelik a klíma megváltozását, s emellett az alkalmazkodás képessége (tudás és anyagiak) is aláhúzandó.

2. táblázat: $A$ válaszadók fontosabb ismérvei az adaptációs cselekvés mentén.

Table 2: Some major features of the respondents according to the adaptation activity.

\begin{tabular}{|l|c|c|}
\hline & $\begin{array}{c}\text { Még nem adaptáló- } \\
\text { dott (N=159) }\end{array}$ & $\begin{array}{c}\text { Már adaptálódott } \\
\text { (N=27) }\end{array}$ \\
\hline Személyes jellemzök & & \\
\hline Férfi & 95,0 & 96,3 \\
\hline Nő & 5,0 & 3,7 \\
\hline 50 év felettiek (1966 elött születettek) aránya & 32,7 & 59,3 \\
\hline Budapestiek aránya & 2,5 & 11,1 \\
\hline 5000 fö alatti településen lakók aránya & 52,2 & 37,0 \\
\hline egyetemi/föiskolai végzettségüek & 82,4 & 92,6 \\
\hline Az erdöterületek jellemzői & & \\
\hline dombvidéki erdészet & 25,8 & 37,0 \\
\hline hegyvidéki erdészet & 40,9 & 37,0 \\
\hline síkvidéki erdészet & 33,3 & 25,9 \\
\hline alföldi erdészet & 27,7 & 25,9 \\
\hline észak-magyarországi erdészet & 23,3 & 22,2 \\
\hline dél-dunántúli erdészet & 21,4 & 29,6 \\
\hline észak-dunántúli erdészet & 27,7 & 22,2 \\
\hline Átlag (10,6\%) feletti bükkös & 32,7 & 25,9 \\
\hline Átlag (11,4\%) feletti gyertyános-tölgyes & 35,8 & 37,0 \\
\hline Átlag (14,2\%) feletti tölgyes & 38,4 & 25,9 \\
\hline Átlag (14,5\%) feletti cseres & 34,0 & 51,9 \\
\hline Átlag (11,4\%) feletti fenyves & 25,2 & 33,3 \\
\hline Átlag (23,5\%) feletti egyéb keménylombos & 37,1 & 33,3 \\
\hline Átlag (14,4\%) feletti egyéb lágylombos & 28,3 & 25,9 \\
\hline Természetvédelmi oltalom 50\% felett & 49,7 & 55,6 \\
\hline Gazdasági rendeltetésü erdő 50\% felett & 62,3 & 59,3 \\
\hline Állami erdögazdaság & & \\
\hline
\end{tabular}




\begin{tabular}{|c|c|c|}
\hline & $\begin{array}{l}\text { Még nem adaptáló- } \\
\text { dott }(\mathrm{N}=159)\end{array}$ & $\begin{array}{l}\text { Már adaptálódott } \\
\quad(\mathrm{N}=27)\end{array}$ \\
\hline \multicolumn{3}{|l|}{ Tapasztalta Ön az éghajlatváltozást? } \\
\hline Igen, az elmúlt néhány évben & 31,6 & 11,1 \\
\hline Igen, az elmúlt 10 évben & 39,9 & 55,6 \\
\hline Igen, már régebb óta & 20,3 & 33,3 \\
\hline \multicolumn{3}{|l|}{$\begin{array}{l}\text { Mennyire érzi fontosnak az éghajlatváltozás } \\
\text { problematikáját? }\end{array}$} \\
\hline $\begin{array}{l}\text { Az éghajlatváltozás a múltban és a jelenben is hatással } \\
\text { volt/van az emberiségre és a jövőben sem lesz ez } \\
\text { másképp }\end{array}$ & 36,1 & 25,9 \\
\hline $\begin{array}{l}\text { A klímaváltozásnak csak a távoli jövőben lesznek } \\
\text { hatásai az emberiségre }\end{array}$ & 3,8 & 3,7 \\
\hline $\begin{array}{l}\text { Az éghailatváltozás csak gyermekeink/unokáink életére } \\
\text { lesz döntő hatással }\end{array}$ & 4,4 & 7,4 \\
\hline $\begin{array}{l}\text { Az éghajlatváltozás hatásait már saját börömön is } \\
\text { érzem, saját szememmel is látom }\end{array}$ & 55,7 & 63,0 \\
\hline Aggódás-index & $\begin{array}{c}\text { Átlag: } 22,6 \\
\text { Range: } 11-30\end{array}$ & $\begin{array}{c}\text { Átlag: } 24,1 \\
\text { Range: } 17-30\end{array}$ \\
\hline Klíma-romlás index & $\begin{array}{c}\text { Átlag: } 8,0 \\
\text { Range: } 0-12\end{array}$ & $\begin{array}{c}\text { Átlag: } 9,2 \\
\text { Range: } 5-12\end{array}$ \\
\hline \multicolumn{3}{|l|}{$\begin{array}{l}\text { Befolyásolja-e az Ön gazdálkodásának eredmé- } \\
\text { nyességét az éghajlatváltozás? }\end{array}$} \\
\hline Igen, sokat romlott & 11,7 & 22,2 \\
\hline Igen, romlott & 64,8 & 66,7 \\
\hline Nem befolyásolta & 12,4 & 11,1 \\
\hline Nem tudja vagy javult & 11,0 & 0,0 \\
\hline \multicolumn{3}{|l|}{ Saját alkalmazkodóképesség megítélése } \\
\hline $\begin{array}{l}\text { Teljesen kiszolgáltatottnak érzem magam, nem tudok } \\
\text { mit tenni }\end{array}$ & 3,4 & 7,4 \\
\hline Kiszolgáltatottnak érzem magam, kevés a mozgástér & 70,3 & 37,0 \\
\hline $\begin{array}{l}\text { Tudom mit kell tenni a sikeres alkalmazkodáshoz, csak } \\
\text { a ráfordítható pénzen múlik }\end{array}$ & 18,6 & 55,6 \\
\hline $\begin{array}{l}\text { Képes vagyok uralni a problémákat, alkalmazkodni a } \\
\text { változásokhoz }\end{array}$ & 7,6 & 0,0 \\
\hline
\end{tabular}

Egy kutatási hipotézisünk arra vonatkozott, hogy professzionálisabbak-e az állami erdészetek. Az aggódás-indexek között mindössze 6 tized különbség van; a magán vagy társulati erdőgazdálkodók árnyalatnyival borúsabbnak látják a jövőt. Némiképp ezzel összefüggésben az állami erdőgazdaságoknál dolgozók 77,8, míg a magán erdőgazdálkodók 79,7\%-a számolt be romló gazdálkodási feltételekről az éghajlatváltozással összefüggésben. A kiszolgáltatottságról beszámolók aránya előbbieknél 67,6 , utóbbiaknál 71,9 volt, vagyis a má- 
sik oldal, a „tudom mit kell tenni”, „képes vagyok uralni a problémákat” válaszokat adók nagyobb arányban voltak az állami erdőgazdálkodóknál. Vagyis e csoport körében árnyalatnyival kisebb a pesszimizmus. A tényleges tevékenységet, a komolyabb felkészülést illetően - a kollégákkal való eszmecserétől a kutatások rendeléséig - a százalékokat összesitve szintén némiképp az állami erdészetek járnak előbbre, jóllehet a már változtatók aránya szinte azonos, ahogy az a 2. táblázatban is látható volt (3. ábra). Végeredményben azt mondhatjuk, hogy nincs lényeges különbség az erdészetek között, ezért a hipotézisünket nem fogadjuk el.

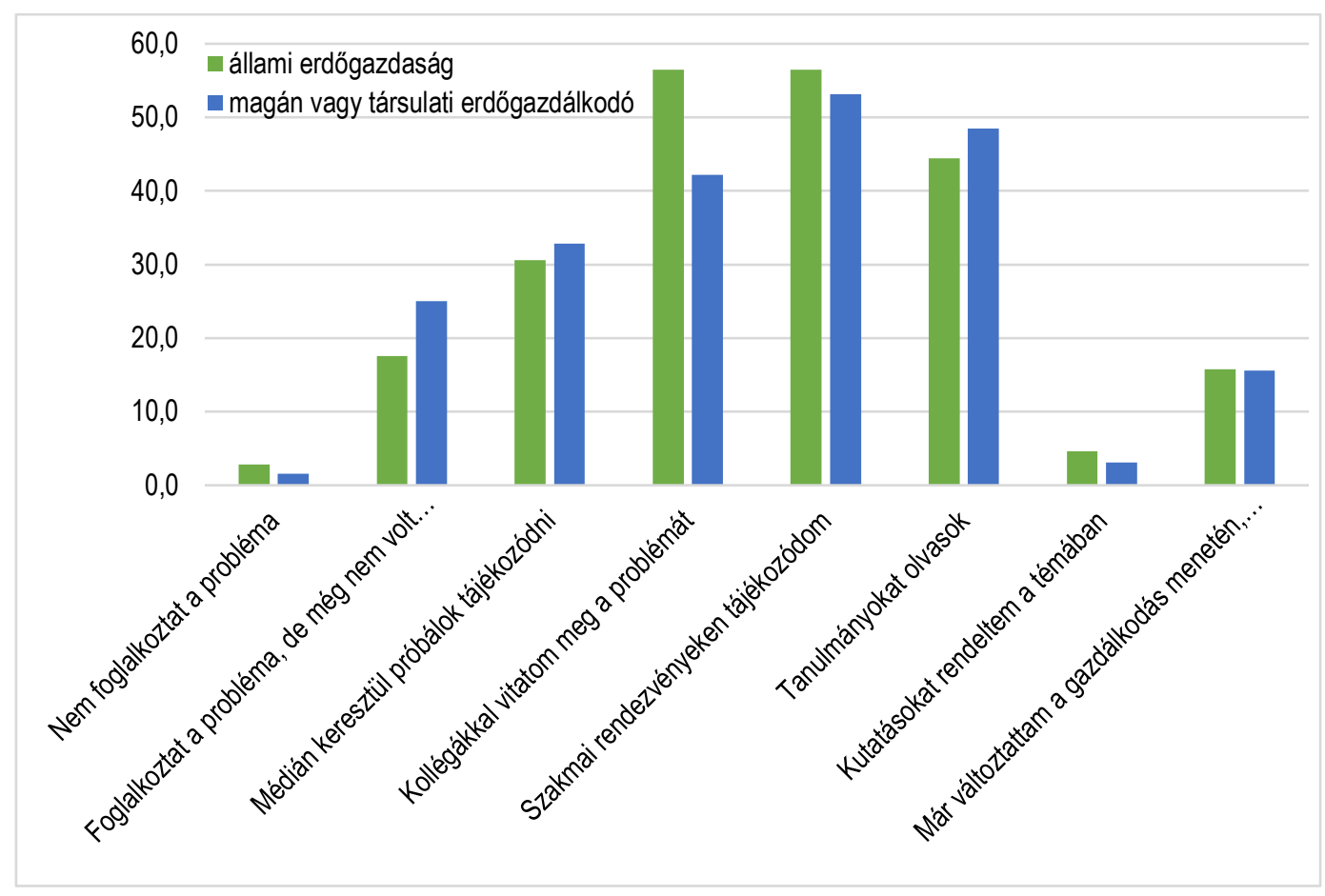

3. ábra: A válaszadók figyelme és az éghajlatváltozás.

Figure 3: Climate change concern of the respondents.

Az alkalmazkodással kapcsolatban a második kérdésünk, hipotézisünk a természetvédelmi oltalomra vonatkozott. Bár a 2. táblázat azt sugallja, hogy van némi összefüggés a természetvédelmi oltalom súlya és az adaptációs cselekvés között, mélyebbre ásva nem ilyen egyértelmű a kép. Az adatsor hisztogramja alapján hasonló elemszámú csoportokra bontottuk a válaszadókat a tekintetben, hogy mekkora általuk kezelt erdő áll valamilyen természetvédelmi oltalom alatt. A gazdálkodás eredményességét leginkább romlónak a negyedik csoport (66,67-90\% természetvédelmi erdö) érzékelte, ezt követte az ötödik, majd az első, legkevesebb védett erdőt kezelök csoportja. Az alkalmazkodóképesség megitélésében 
szintén nem egyirányú a felsejlő összefüggés, a magas és alacsony arányú természetvédelmi oltalommal jellemezhető csoportoknál nagyobb arányú a kiszolgáltatottság, míg a közepes kategóriákban, a magabiztosság nagyobb (4. ábra).

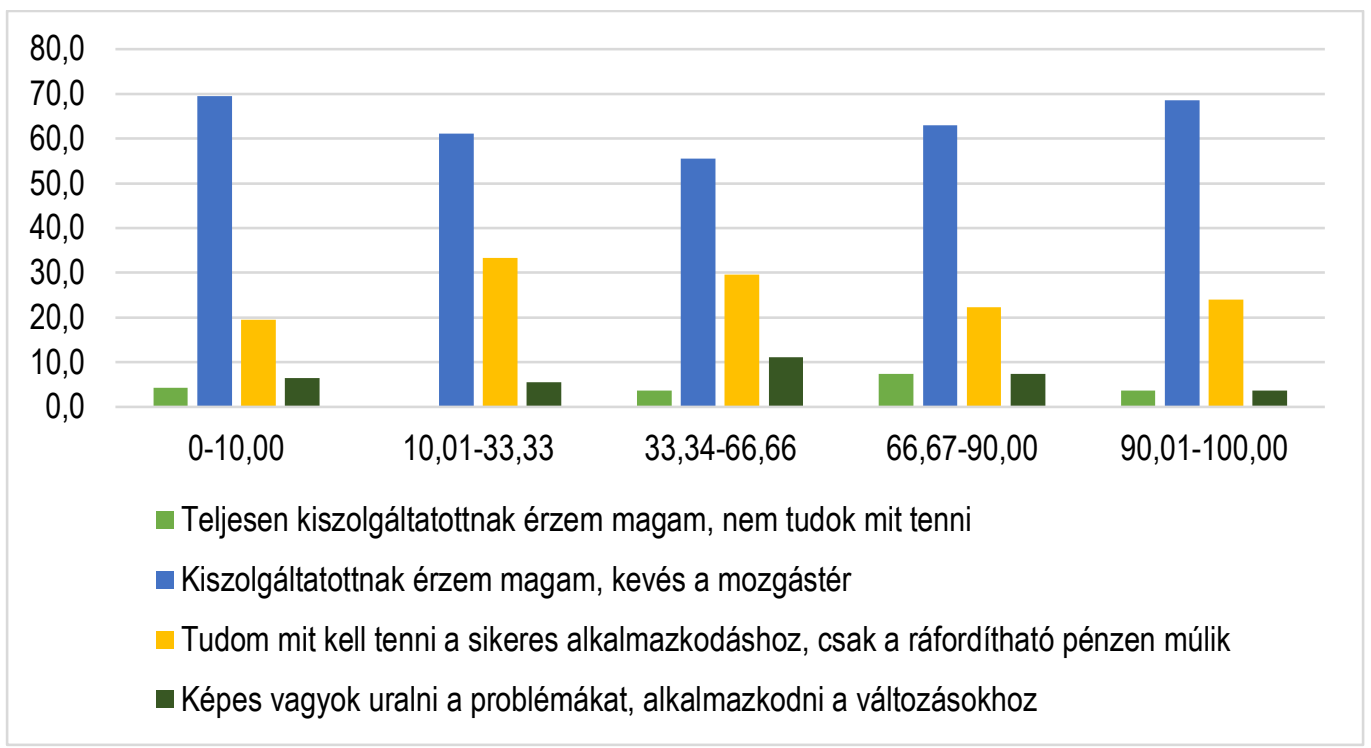

4. ábra: Az alkalmazkodóképesség megitélése. A válaszadók csoportjai kezelt erdőterületeik természetvédelmi oltalma (\%) függvényében.

Figure 4: Evaluation of climate change adaptation skills. Groups are displayed according to the rate of nature protection in managed forest areas (\%).

Az adaptációs felkészülést illetően hasonló a helyzet: leginkább a középső csoportok tettek már valamit az éghajlatváltozáshoz való alkalmazkodás érdekében, és nagyobb fokú a felkészülési tevékenységük. Egyértelmü statisztikai összefüggésröl a természetvédelem alatt álló erdőknél nem lehet beszámolni, hipotézisünket ez esetben el kellene vetnünk. Ugyanakkor az interjúk arra engednek következtetni, hogy a természetvédelmi oltalom megnehezíti az innovatív jellegü adaptációs kezdeményezéseket, illetve a szigorúbb szabályozások merevvé teszik a rendszert, kevés a mozgástér.

Utolsó vizsgálati szempontunk, hogy az aggódás milyen összefüggésben van a cselekvőképességgel, blokkolja-e a túlzott pesszimizmus, jövőfélés a cselekvést, vagyis megfigyelhető-e az a pszichológiából ismert tétel, miszerint a túlzott szorongás ugyanúgy negatívan hat a cselekvésre, mint a problémák lebecsülése. Ehhez a vizsgálathoz az aggódási indexek eloszlása (hisztogramja) alapján képeztünk hat csoportot, majd ezeket két kérdésre adott válaszokkal ütköztettük. Az alkalmazkodási képesség esetén nem fedezhetünk fel összefüggést az aggódás mértékével, a felkészülés-tevékenység változtatásnál már némiképp értelmezhetőbb az összefüggés. Aki minimálisan aggódik (első kategória), az kevéssé foglalkozik a témával, felkészülési aktivitása alacsony, változtatást még nem eszközölt gazdálko- 
dása menetén, viszont a sor másik végén, a leginkább aggódók igen aktívak mind a felkészülés, mind a cselekvés terén (vö. 2. táblázat). Igaz utóbbinál nincs egyértelmü kapcsolat az aggódás mértékével. Viszont érdekes az, hogy az aggódás mértékének sorrendjében egyre inkább szerepet játszik a médiában való tájékozódás, és a legmagasabb aggódásiindexszel jellemezhető csoportnál már a többi csoporthoz képest kétszer akkora szerepet játszik a média a tájékozódás terén. Lehetséges, hogy a jelentősebb média-fogyasztás vezet a nagyobb mértékű aggódáshoz? Vagy nagyobb aggódás miatt fogyasztunk több vonatkozó média tartalmat? Az igazság inkább valahol középütt lehet. A szakmai felkészülési típusok között - kollégáktól a kutatásokig - nincs egyértelmü összefüggés, bár a legmagasabb értéket a leginkább aggódók produkálták, igaz a közbülső csoportoknál már összekeveredik a sorrend. Végeredményben ide vonatkozó hipotézisünket is el kell vetnünk, a túlzott aggódás nem vezet cselekvőképtelenséghez, sőt, inkább azt mondhatjuk, hogy nagyobb aggódás jelentősebb felkészülési tevékenységet vált ki a válaszadókból.

\section{A végrehajtott és a tervezett adaptáció}

Azok a gazdálkodók, akik a megkezdett alkalmazkodásukról számoltak be (Id. 3. ábra), a következő nyitott kérdésben fejtették ki annak mikéntjét. E 26 válaszadó közül mintegy 14en változtattak a telepített fafajokon, az állományok fajösszetételén, ketten az öntözést, talajművelést említették, többen, 22-en pedig az erdőkezelési, -felújitási és -védelmi módok terén avatkoztak be.

Míg az alkalmazkodást tehát kevesen kezdték meg, a jövőre vonatkozó tervekkel azonban az éghajlatváltozást tapasztaló 159 megkérdezett 80\%-a rendelkezik, viszont ebből is mintegy $10 \%$ egyelöre csak a felkészülés különbözö formáit említette (kutatások rendelése, szakirodalom olvasása, mérōállomás telepítése stb.). A válaszadóknak így $68,5 \%$-a az, akik konkrét elképzelésekkel rendelkeznek, $s$ tudni vélik, hogy mi lenne a megoldás a megváltozott körülményekhez való alkalmazkodásban.

Megjegyzendő azonban, hogy többek szerint ehhez felül kellene vizsgálni a jelenleg érvényben lévő szabályozó rendszert, ezt többen megerősítették az interjúalanyok közül is, ahol elhangzott, hogy a természet, az erdő alkalmazkodik a klímaváltozásához, és ezt a szakmának be kell látnia, s ezzel összefüggésben szükség lenne az erdögazdálkodás és a természetvédelem közötti párbeszédre, illetve kompromisszumokra, mert a helyesen megválasztott fafajpolitika a jövőre nézve, mind ökológiai, gazdálkodói, de klímavédelmi szempontból is elengedhetetlen. Megkérdezetteink szerint tehát a bürokrácia, a törvényi szabályozás, a túlzott természetvédelmi elöírások jelentik a legnagyobb akadályt az erdőgazdálkodóknak az alkalmazkodási cselekvésében, mely egyrészt lehetetlenné teszi a gyors reakciót, másrészt elveszi a kedvét az újitani, kísérletezni próbáló gazdálkodóknak. Néhány gazdálkodó ugyanakkor arról számolt be, hogy sikerült az újitásokat a természetvédelemmel egyeztetve keresztülvinni, és eredményeket elérni (pl. ökológiai vízpótlás, minitavak rend- 
szere). Többen említették, hogy nagyobb önállóságot kellene adni a helyi ismerettel, tapasztalattal rendelkező gazdálkodónak, és megbízni a tudásukban, szándékukban, míg mások kiemelték a tudomány felelősségét, az erdész szakma oktatási, képzési rendszereinek átalakitását is, illetve a szemléletváltás fontosságát.

A kérdőívnél a határozott véleményt megfogalmazók közül 10\% a termőhelyi körülmények (klíma, hidrológiai viszonyok, talaj) javítását tervezi elvégezni, 47\% említette, hogy a megváltozott körülményekhez igazodva a faállomány összetételén változtatva, esetleg új fajok alkalmazásával tervezi a beavatkozást, $20 \%$ pedig az erdőkezelési, erdőfelújítási, erdővédelmi technológiák terén avatkozna be. A jövőbeni tervek kapcsán nagyobb az igénye az ültetendő fafajok megváltoztatásának, mint a már megvalósított adaptációs lépések esetében. Az interjúknál a tárgyalt adaptációs tevékenységek között az elegyes erdőszerkezet átalakitás, a fafajcserék és nevelővágások említhetők még, de sokan megemlítették itt is, hogy az öshonos fafajok mellett teret kellene adni az idegenhonos fafajoknak is, mások viszont teljesen elutasították ezt.

\section{KÖVETKEZTETÉSEK}

Eredményeink alapján megállapítható, hogy a hazai erdésztársadalom a felkészülés fázisában van az éghajlatváltozással kapcsolatban, jelentős a szakmai figyelem a témában, azonban megvalósított adaptációról csak a válaszadók 16\%-a számolt be, ami a külföldi kutatási eredményekkel összevetve alacsonynak mondható. Ugyanakkor többen jelezték, hogy ebben a jogszabályi előirások képeznek számukra akadályt, ennek alapján is fontolóra lehet venni a tudománykommunikáció, illetve a szakpolitikai, a szabályzói környezet módosítását, hogy segítsék az ágazat felkészülését, és alkalmazkodását a megváltozó klímához (Mátyás 2006b, 2016). Tanulmányunk fontos jelzése ezzel összefüggésben, hogy a már alkalmazkodást megvalósítók több mint fele próbálkozott az ültetett fafajokkal kapcsolatosan változtatásokat eszközölni, jóllehet többen voltak azok, akik a kezelési, felújitási módszereken változtattak, ugyanakkor a cselekvést tervezők számára a fafajok kérdése szerepelt az első helyen.

Míg az éghajlatváltozás érzékelésénél eredményeink rámutattak az erdőterületek elhelyezkedésének és fafaj-összetételének befolyásoló szerepére, az alkalmazkodás tekintetében megfogalmazott hipotéziseinket csak részben tudtuk igazolni, ezért aláhúzandó, hogy az állami erdőgazdaságok nem alkalmazkodnak jobban, mint a magán erdészetek, várakozásunkkal ellentétben a természetvédelmi tényezőt sem tudtuk statisztikailag hátráltató tényezőnek kimutatni, s a magas fokú aggódásról sem mondható el, hogy blokkolná az éghajlatváltozáshoz történő alkalmazkodást. Sőt, a már alkalmazkodást megvalósítókról kijelenthető, hogy közöttük átlagban nagyobb fokú az aggódás, továbbá régebb óta érzékelik a problémát, $s$ azt jelentősebb problémának tekintik, saját gazdálkodásuk eredményességét tekintve is. 


\section{KÖSZÖNETNYÍLVÁNÍTÁS}

Kutatásunkat az Agrárklíma.2 - VKSZ_12-1-2013-0034 elnevezésű projekt támogatta. Köszönettel tartozunk Jagicza Attilának, a Bakony Erdő Zrt. Üzemtervezési és Szakfelügyeleti Osztályvezetőjének a kérdőívek kidolgozásában nyújtott segítségéért, Nagy Csabának, a Roth Gyula Szakgimnázium, Szakközépiskola és Kollégium erdőmérnök szaktanárának a kérdőiv elemzésében nyújtott segítségéert, illetve a kérdőívet kitöltö, interjúalanyként információt adó erdészeknek.

\section{FELHASZNÁLT IRODALOM}

Akerlof K., Maibach E.W., Fitzgerald D., Cedeno A.Y. \& Neuman A. 2013: Do people "personally experience" global warming, and if so how, and does it matter? Global Environmental Change 23: 81-91. DOI: 10.1016/j.gloenvcha.2012.07.006

Andersson E., Keskitalo E.C.H. \& Lawrence A. 2017: Adaptation to Climate Change in Forestry: A Perspective on Forest Ownership and Adaptation Responses. Forests 8: 493. DOI: 10.3390/f8120493

Blades J.J., Klos P.Z., Kemp K.B., Hall T.E., Force J.E., Morgan P. et al. 2016: Forest managers' response to climate change science: Evaluating the constructs of boundary objects and organizations. Forest Ecology and Management 360: 376-387. DOI: 10.1016/j.foreco.2015.07.020

Blennow K. 2012: Adaptation of forest management to climate change among private individual forest owners in Sweden. Forest Policy and Economics 24: 41-47. DOI: 10.1016/j.forpol.2011.04.005

Blennow K., Persson J., Tomé M. \& Hanewinkel M. 2012: Climate Change: Believing and Seeing Implies Adapting. PLoS ONE 7(11): e50182. DOI: 10.1371/journal.pone.0050182

Blennow K., Persson J., Persson E. \& Hanewinkel M. 2016: Forest Owners' Response to Climate Change: University Education Trumps Value Profile. PLoS ONE 11(5): e0155137. DOI: 10.1371/journal.pone.0155137

Brace C. \& Geoghegan H. 2010: Human geographies of climate change: Landscape, temporality, and lay knowledges. Progress in Human Geography 35(3): 284-302. DOI: $10.1177 / 0309132510376259$

Broomell S.B., Budescu D.V. \& Por H-H. 2015: Personal experience with climate change predicts intentions to act. Global Environmental Change 32: 67-73. DOI: 10.1016/j.gloenvcha.2015.03.001

Detten R. von \& Faber F. 2013: Organizational decision-making by German state-owned forest companies concerning climate change adaptation measures. Forest Policy and Economics 35: 57-65. DOI: 10.1016/j.forpol.2013.06.009

Egan P.J. \& Mullin M. 2012: Turning Personal Experience into Political Attitudes: The Effect of Local Weather on Americans' Perceptions about Global Warming. Journal of Politics 74(3): 796-809. DOI: 10.1017/s0022381612000448

Furness R. \& Nelson H. 2012: Community forest organizations and adaptation to climate change in British Columbia. The Forestry Chronicle 88: 519-524. DOI: 10.5558/tfc2012-099

Gameren V. van \& Zaccai E. 2015: Private forest owners facing climate change in Wallonia: Adaptive capacity and practices. Environmental Science and Policy 52: 51-60. DOI: 10.1016/j.envsci.2015.05.004

Hamilton L.C. \& Stampone M.D. 2013: Blowin' in the Wind: Short-Term Weather and Belief in Anthropogenic Climate Change. Weather, Climate and Society 5: 112-119. DOI: 10.1175/wcas-d-12-00048.1

Johnston M. \& Hesseln H. 2012: Climate change adaptive capacity of the Canadian forest sector. Forest Policy and Economics 24: 29-34. DOI: 10.1016/j.forpol.2012.06.001

Lawrence A. \& Marzano M. 2014: Is the private forest sector adapting to climate change? A study of forest managers in north Wales. Annals of Forest Science 71(2): 291-300. DOI: 10.1007/s13595-013-0326-4 
Lakkonen A., Zimmerer R., Kähkönen T., Hujala T., Takala T. \& Tikkanen J. 2018: Forest owners' attitudes toward pro-climate and climate-responsive forest management. Forest Policy and Economics 87: 1-10. DOI: 10.1016/j.forpol.2017.11.001

Lenart M. \& Jones C. 2014: Perceptions on climate change correlate with willingness to undertake some forestry adaptation and mitigation practices. Journal of Forestry 112(6): 553-563. DOI: 10.5849/jof.13-051

Lorenzoni I. \& Pidgeon N. F. 2006: Public views on climate change: European and USA perspectives. Climatic Change 77: 73-95. DOI: 10.1007/s10584-006-9072-z

Mátyás Cs. 2006a: Az előrejelzett klímaváltozás és a magyar erdőtakaró sorsa. In: Fekete G. \& Varga Z. (eds): Magyarország tájainak növényzete és állatvilága. MTA, Budapest 420-424.

Mátyás Cs. 2006b: Gének, ökoszisztémák, gazdálkodás: erdészet, paradigmaváltás után: MTA Székfoglaló előadás. Acta Silvatica et Lignaria Hungarica 2: 5-24.

Mátyás Cs. 2016: Az erdészeti szaporítóanyag megválasztása a klímaváltozás fényében. Erdészeti Lapok 151(3): 78-82.

Mátyás Cs. \& Sun G. 2014: Forests in a water limited world under climate change. Environmental Research Letters 9(8): 085001. DOI: 10.1088/1748-9326/9/8/085001

Milad M., Schaich H. \& Konold W. 2012: How is adaptation to climate change reflected in current practice of forest management and conservation? A case study from Germany. Biodiversity and Conservation 22: 1181-1202. DOI: 10.1007/s10531-012-0337-8

Mostegl N.M., Pröbstl-Haider U., Jandl R. \& Haider W. 2017: Targeting climate change adaptation strategies to small-scale private forest owners. Forest Policy and Economics (In Press). DOI: 10.1016/j.forpol.2017.10.001

Myers T.A., Maibach E.W., Roser-Renouf C., Akerlof K. \& Leiserowitz A.A. 2013: The relationship between personal experience and belief in the reality of global warming. Nature Climate Change 3: 343-347. DOI: 10.1038/nclimate1754

Nelson H., Williamson T.B., Macaulay C. \& Mahony C. 2016: Assessing the potential for forest management practitioner participation in climate change adaptation. Forest Ecology and Management 360: 388-399. DOI: 10.1016/j.foreco.2015.09.038

NES 2016: Nemzeti Erdőstratégia 2016-2030. Földművelésügyi Minisztérium Erdészeti és Vadgazdálkodási Főosztály, Budapest, 2016. szeptember.

Petr M., Boerboom L., Ray D. \& van den Veen A. 2014: An uncertainty assessment framework for forest planning adaptation to climate change. Forest Policy and Economics 41: 1-11. DOI: 10.1016/j.forpol.2013.12.002

Raftoyannis Y., Nocentini S., Marchi E., Sainz R.C., Guemes C.G., Pilas I. et al. 2014: Perceptions of forest experts on climate change and fire management in European Mediterranean forests. iForest - Biogeosciences and Forestry 7: 33-41. DOI: 10.3832/ifor0817-006

Somogyi Z. 2003: Erdők nélkül? L'Harmattan, Budapest.

Sousa-Silva R., Ponette Q., Verheyen K., Van Herzele A. \& Muys B. 2016: Adaptation of forest management to climate change as perceived by forest owners and managers in Belgium. Forest Ecosystems 3(1): 22. DOI: 10.1186/s40663-016-0082-7

Weber E.U. 2010: What shapes perceptions of climate change? Wiley Interdisciplinary Reviews: Climate Change 1: 332-342. DOI: $10.1002 / w c c .41$

Yousefpour R. \& Hanewinkler M. 2015: Forestry professionals' perceptions of climate change, impacts and adaptation strategies for forests in south-west Germany. Climatic Change 130(2): 273-286. DOI: 10.1007/s10584-015-1330-5

Érkezett: 2018. május 3.

Közlésre elfogadva: 2018. június 1. 